\title{
Effect of Agro- organic wastes and NPK Fertilizer on Upland Rice Performance in Port Harcourt, Rivers State, Nigeria
}

\section{Orluchukwu, J.A.; Emem, Alban; Omovbude, S.}

\author{
Department of Crop and Soil Science, Faculty of Agriculture, University of Port Harcourt, \\ P. M. B. 5323, Choba, Port Harcourt, Rivers State, Nigeria.
}

\section{ARTICLE INFO}

Article No.: 030919045

Type: Research

DOI: 10.15580/GJAS.2019.1.030919045

Submitted: 09/03/2019

Accepted: 12/03/2019

Published: $30 / 03 / 2019$

*Corresponding Author

Dr. Omovbude, $S$.

E-mail: sundayomovbude@

yahoo.com

Phone: +2348053186814

Keywords: Agro- organic wastes, NPK fertilizer, upland

Rice, performance
ABSTRACT

Field experiment was conducted to evaluate the effect of agro organic wastes against NPK fertilizer on upland rice performance in Port Harcourt, Rivers State, Nigeria. The experiment was conducted at the Teaching and Research Farm of the University of Port Harcourt. The experiment consisted of five (5) treatments namely: 0 (control), $300 \mathrm{~kg} / \mathrm{ha}$ NPK (15 - 15- 15) Fertilizer, 10 t/ha poultry manure (poultry droppings), 10 t/ha spent mushroom substrate, 5 t/ha poultry manure +5 t/ha spent mushroom substrate. The treatments were laid out in a randomized complete block design (RCBD) with four (4) replications. The study showed that there were no significant differences among the treatments on growth attributes (plant height and leaf area), yield and yield components (number of tillers, fresh weight of tillers, dry weight of tillers, dry weight of panicle, 1000 dry weight of grains and grain yield) although 5 t/ha poultry manure $+5 \mathrm{t} / \mathrm{ha}$ spent mushroom substrate tended to produce higher growth attributes, yield and yield components compared to other treatments. The control (where no treatment was added) gave the lowest growth attributes, yield and yield components. Therefore, the combination of $5 \mathrm{t} / \mathrm{ha}$ poultry manure $+5 \mathrm{t} / \mathrm{ha}$ spent mushroom substrate is recommendable to upland rice farmers in the area of study since they complement each other and served as a better alternative to NPK (15: 15: 15) fertilizer, which is scarce and expensive. 


\section{INTRODUCTION}

Rice (Oryza sativa L.) belongs to the family Poaceae and is one of the most consumed staples in Nigeria (PwC, 2018). More than 90 per cent of total rice is cultivated in South and East Asia, having China and India as the leading producers (Remison, 2005). Globally, Nigeria is the highest importer of rice and the largest producer in West Africa (Anon, 2019). Generally, mass importation of rice from Asian countries is high in African countries because Africa countries account for 2 per cent of production (Remison, 2005). There are two main types of rice cultivation viz: upland and swamp rice. Upland rice is planted in soils without irrigation or flooding. It depends solely on seasonal rainfall while swamp rice is cultivated in places which are naturally flooded by rain water or in areas artificially flooded by irrigation.

In West Africa, upland rice accounts for 75 per cent of rice cultivation (Remison, 2005) while in Nigeria it accounts for about 30-35 per cent of total rice production and swamp rice accounts for about 25 per cent (Singh et al., 1997; Idiong, 2006) . Upland is cultivated in all parts of the states in Nigeria but predominantly in Abia, Bauchi, Benue, Borno, Delta, Ebonyi, Edo, Ekiti, Enugu, Gombe, Jigawa, Imo, Kaduna, Kastina, Kebbi, Kwara, Kogi, Nassarawa, Niger, Ogun, Ondo, Oyo, Osun, Sokoto, Plateau, Yobe, Zamfara, Taraba and FCT (Rapu, 2016). Although yield per hectare is low in this system; however, Southern states tend to have a more encouraging yield than northern states probably because of higher rainfalls (Fakayode, 2009).

Upland production is common among Nigerian farmers because of unlimited land areas and less difficulty in cultivation when compared to low land rice. In the upland environment, rice cultivation is faced by many problems such as: drought, low adoption of improved varieties, soil acidity and general soil infertility, poor weed control, limited capital investments, and labour shortages, and low mechanization; yields range from 1.0 to $1.7 \mathrm{t} /$ ha compared with a potential of 2.0-4.0 $\mathrm{t} / \mathrm{ha}$ (Anon, 2019). Among these problems, general soil infertility is of uppermost importance. The average rice farm holding in Nigeria is between 1 to 2 hectares (Akpokodje et al., 2001).

In addressing the problem of soil infertility, farmers tend to use chemicals fertilizers. However, fertilizers at most times are not available and are expensive for poor farmers to buy. Even when occasionally available, improper application for continuous crop production can lead to environmental pollution, soil degradation and consequently lower crop yields. Due to the shortcomings of inorganic manure, the need to investigate alternative sources of maintaining soil fertility such as organic manure comes into focus. Organic manure mainly comes from crop residues and animal by-products like meat, bone meal, blood meal, fecal materials, etc. They contain specifically high levels of nutrients (e.g. N, P K).
They have high organic matter contents and a variety of micronutrients (Busari and Salako).

The recent increase in demand for cereals (rice in particular) has become a source of worry to people both locally and internationally. The problem stems from the fact that the world's population is increasing astronomically, which has put more pressure on the consumption of rice and its use as raw materials in industries. The urgent need to increase rice production in Nigeria and to expand the scope of rice production in the midst of inadequate and high cost of chemical fertilizer necessitated this study. Hence, the objective of this current study was to determine the effect of agro organic manure wastes and NPK fertilizer on the yield of upland rice in Port Harcourt, Rivers State, Nigeria.

\section{MATERIALS AND METHODS}

\section{Description of the Site}

The experiment was conducted at the Teaching and Research Farm of the University of Port Harcourt, Port Harcourt, Choba, Rivers State, Nigeria during the early cropping season of 2017. The experimental site is located at latitude $04^{\circ} 54^{\prime} 538^{\prime} \mathrm{N}$ and longitude $006^{\circ} 55^{\prime}$ $329^{\prime} E$ with an elevation of $17 \mathrm{~m}$ above sea level. It has an average temperature of $27^{\circ} \mathrm{C}$, relative humidity of $78 \%$ and an average rainfall that ranges from 2500 $4000 \mathrm{~mm}$ (Nwankwo and Ehirim 2010). It is characterized by tropical wet (March to October) and dry (NovemberFebruary) seasons.

The experimental site was dominated by weed species such as: Ageratum conyzoides Linn., Aspilia africana (Pers.) C.D. Adams, Chromoleana odorata (L.) R.M. King \& Robinson, Cleome rutidosperma DC., Commelina diffusa Burm. F., Cyperus esculentus Linn. Cyperus rotundus Linn. Euphorbia heterphylla Linn., Kyllinga erecta Schumach, Mariscus alternifolius Vahl., Mitracapus villosus (Sw.) DC. Oldenlandia corymbosa Linn., Panicum maximum Jacq., Phyllanthus niruri var. amarus (Schumach. \& Thonn.) Learndri, and Sida cordifolia Linn. The soil was under continuous cultivation with crops such as cassava, sweet potatoes, fluted pumpkin and maize for five years. The soil is acidic and belongs to the order known as Ultisol. Ultisol usually has low pH and low nutrients (Brady \& Weil, 2008).

\section{Source of materials}

NPK (15 - 15-15) fertilizer was bought from the agrochemical distributors and poultry manure (poultry droppings) from a small scale poultry farmer at Choba, Port Harcourt, Rivers State. Spent mushroom substrate was obtained from the University of Port Harcourt mushroom unit. The rice variety, Faro 52 was bought from International Institute of Tropical Agriculture (IITA), Ibadan, Oyo State. 


\section{Soil and agro organic wastes (poultry manure and spent mushroom) analysis}

\section{Soil Analysis}

Soil samples were taken diagonally at a uniform depth of $0-15 \mathrm{~cm}$ from 15 points on the experimental site using a soil auger of $10 \mathrm{~cm}$ diameter. The soil samples were bulked, air dried and a representative sample was taken after processing for laboratory analysis. Particle-size analysis was determined by hydrometer method (Sheldrick and Hand Wang, 1993) and soil $\mathrm{pH}$ in a (1:2) soil: water ratio suspension using a digital electronic $\mathrm{pH}$ meter. Soil organic carbon was by the Walkley and Black procedure by wet oxidation using chromic acid digestion (Nelson and Sommers 1996). Total $\mathrm{N}$ was determined using micro-Kjeldahl digestion and distillation techniques (Bremner, 1996). Available P was determined by Bray II method (Olsen and Sommers, (1982). Exchangeable K, Ca and Mg were extracted with a $1 \mathrm{M} \mathrm{NH} 4 \mathrm{OAc}, \mathrm{pH} 7$ solution. Thereafter, $\mathrm{K}$ was analysed with a flame photometer and $\mathrm{Ca}$ and $\mathrm{Mg}$ were determined with an atomic absorption spectrophotometer (Okelabo et al., 2002)

\section{Agro organic wastes analysis}

After the processing of poultry manure and spent mushroom substrate, small samples were taken for laboratory analysis to determine their chemical compositions. Organic carbon was determined by the Walkely and Black procedure using the dichromate wet oxidation method (Nelson and Sommers 1996), total N by micro-Kjeldahl digestion followed by distillation and titration (Bremner, 1996). While P, K, Na, Ca and $\mathrm{Mg}$ was carried out using the wet digestion procedure; established on $25-5-5 \mathrm{ml}$ of $\mathrm{HNO}_{3}-7 \mathrm{H}_{2} \mathrm{SO}_{4}-7 \mathrm{HClO}_{4}$ (Horwitz, 1997). Phosphorus was determined calorimetrically by the molybdate blue method in an auto-analyser, $\mathrm{K}$ by flame photometry, and $\mathrm{Ca}$ and $\mathrm{Mg}$ by atomic absorption spectrophotometer (Okalebo et al. 2002). Soil pH was determined using the same procedures used for soil analysis.

\section{Treatments and Experimental Design}

The experiment consisted of five treatments namely: 0 (control), $300 \mathrm{~kg} / \mathrm{ha}$ NPK (15 - 15- 15) Fertilizer, $10 \mathrm{t} /$ ha poultry manure (poultry droppings), 10 t/ha spent mushroom substrate, 5 t/ha poultry manure + $5 \mathrm{t} /$ ha spent mushroom substrate. The treatments were laid out in a randomized complete block design (RCBD) with four (4) replications.

\section{Cultural details}

Experimental land area of $20 \mathrm{~m} \times 16 \mathrm{~m}\left(320 \mathrm{~m}^{2}\right)$ of approximately 0.032 ha was cleared manually; stumps and debris were packed without burning. The experimental area was divided into four blocks while each block was further divided into five (5) plots making it 20 plots. Each plot size was $3 \mathrm{~m} \times 3 \mathrm{~m}$. The plots were separated by $1 \mathrm{~m}$ while the blocks were separated with a pathway of $1 \mathrm{~m}$. Poultry manure was cured for seven days and applied at $10 \mathrm{t} / \mathrm{ha}$. Spent mushroom substrate was processed for seven days and applied at $10 \mathrm{t} / \mathrm{ha}$. The mixture of poultry manure and spent mushroom was half rates of poultry manure and spent mushroom substrate ( 5 tonnes of poultry manure +5 tonnes of spent mushroom substrate). Poultry droppings in form of poultry manure and spent mushroom substrate was applied at a week before sowing. The seeds were sown on the $18^{\text {th }}$ of May 2017. The planting distance within and between rows was $30 \mathrm{~cm} \times 30 \mathrm{~cm}$. The seed rate was three seeds per hole and later thinned to one seedling per stand at two weeks after sowing (2 WAS) to give a plant population of 64 plants per plot of approximately 71,111 plants per hectare. NPK 15-15-15 fertilizer was applied at a recommended rate of $300 \mathrm{~kg}$ /ha using ring method of application at three weeks after sowing ( 3 WAS). Hoe weeding was carried in all the plot at 3 and 7 WAS. Birds were scared away especially during the milking stage by Human bird scarers.

\section{Data collection}

Data were collected at weekly intervals starting from 6 weeks after sowing (WAS). Data were taken randomly from three plants from each plot. The following parameters were taken: plant height, number of tillers, leaf area (leaf length and leaf width 0.75 , Remison and Lucas, 1982), fresh weight of tillers, dry weight of tillers, dry weight of panicles, dry weight of 1000 grains and grain yield.

\section{Statistical analysis}

Data collected were subjected to analysis of variance (ANOVA) using SAS (2003) statistical package and means were separated by using least significant difference (LSD) at $5 \%$ level of probability.

\section{RESULTS AND DISCUSSION}

\section{Soil and Agro- organic wastes Analysis}

Some of the physico-chemical characteristics of the soil at the experimental site are presented in Table 1. In texture, the soil was sandy loam with sand, silt and clay contents of $76.1 \%, 11 \%$ and $2.9 \%$. The relative high sand content in the experimental site could be due to the nature of the parent material. Akamigbo and Asadu (1983) noted that parent materials of the soils of Southeastern Nigeria are influenced by the texture of the soils. The $\mathrm{pH}$ of the soil was slightly acidic and it fell within the range of 5.5 to 6.5 required for upland rice production in Nigeria.

The soil had a low organic matter content of 1.29 $\%$ as against the critical value of $2.0 \%$ reported by lbedu 
et al. (1988). The low organic carbon and organic matter of the soil could be attributed to insufficient organic litter and continuous crop cultivation. It could also be attributed to high fraction of sand.

The total $\mathrm{N}$ content of the soil $(0.07 \%)$ was low compared with the critical value of $0.15 \%$ in southeastern soil (lbedu et. al., 1988). The low value of nitrogen might be attributed to continuous cropping, mineralization and the leaching effect caused by intensive rainfall that is common in South-eastern Nigeria. Available phosphorus with Bray II method of extraction was low compared with the critical level of 15 $\mathrm{mg} / \mathrm{kg}$ reported by lbedu et al. (1988), in Southeastern soil of Nigeria probably as a result of $P$ fixation. Fixation occurs when $P$ reacts with other minerals to form insoluble compounds and becomes unobtainable to crops uptake. The soil was low in exchangeable cations against their critical level of $0.5 \mathrm{cmol} / \mathrm{kg}$ for $\mathrm{Ca}, \mathrm{Mg}(0.30$ $\mathrm{cmol} / \mathrm{kg}) \mathrm{K}(0.20 \mathrm{cmol} / \mathrm{kg})$ respectively for soil in South- eastern Nigeria (Ibedu et al., 1988). This might be attributable to weathering of parent material, leaching and intensive cultivation.

The chemical properties of the agro organic wastes before planting are presented in Table 1. The $\mathrm{pH}$ of poultry manure and spent mushroom substrate were close to neutral. Spent mushroom substrate had a higher $\mathrm{C} / \mathrm{N}$ ratio than poultry manure which implies that it decomposes faster and releases nutrients into soil than spent mushroom substrate. Poultry manure had a higher content of $\mathrm{N}, \mathrm{P}, \mathrm{K}, \mathrm{Mg}$ and $\mathrm{Ca}$ than spent mushroom substrate. Generally, both agro organic wastes were higher in nutrients $(\mathrm{N}, \mathrm{P}, \mathrm{K}, \mathrm{Mg}$ and $\mathrm{Ca}$ ) and lower in $\mathrm{C} / \mathrm{N}$ ratio than the soil used for the experiment. The $\mathrm{C} / \mathrm{N}$ ratio of both agro organic wastes were lower than 20 reported by Spanish legislation for organic manure Gil et al. (2008), which implies that the rate of mineralization of both agro organic wastes are higher than immobilization (Busari et al., 2008).

Table 1: Some chemical properties of the soil and agro - organic wastes before sowing

\begin{tabular}{|l|l|l|l|}
\hline Composition & Soil & $\begin{array}{l}\text { Poultry } \\
\text { manure }\end{array}$ & $\begin{array}{l}\text { Spent mushroom } \\
\text { substrate }\end{array}$ \\
\hline Physical properties & & & \\
\hline Sand (\%) & 76.10 & & \\
\hline Silt $(\%)$ & 11.00 & & \\
\hline Clay (\%) & 2.90 & & \\
\hline Textural class & Sandy loam & & \\
\hline Chemical properties & & & \\
\hline pH (H20) & 6.02 & 6.60 & 6.62 \\
\hline Total organic carbon $(\%)$ & 0.75 & 2.7 & 2.01 \\
\hline Organic matter $(\%)$ & 1.29 & 4.65 & 3.47 \\
\hline Total nitrogen $(\%)$ & 0.07 & 0.29 & 0.20 \\
\hline C/N ratio & 10.71 & 9.31 & 10.05 \\
\hline Available P (mg/kg) & 7.27 & 19.13 & 12.95 \\
\hline Cation exchange capacity (Cmol/kg) & & & \\
\hline Ca & 0.40 & 0.36 & 0.34 \\
\hline Mg & 0.23 & 0.28 & 0.24 \\
\hline $\mathrm{K}$ & 0.10 & 0.24 & 0.16 \\
\hline
\end{tabular}

\section{Growth attributes}

\section{Plant height}

The effect of agro organic wastes and NPK fertilizer on plant height of upland rice is presented in Table 2. Gradual increase in plant height was noticed throughout the sampling time as the plant ages. There was no significant difference on plant height of rice throughout the various time of sampling. Although there were no significant differences on plant height among the treatments throughout the intervals of sampling, plot treated with the combination of $5 \mathrm{t} /$ ha poultry manure +5 t/ha spent mushroom substrate produced the tallest plant while the control had the shortest plant. The probable reason for the combination of 5 t/ha poultry manure $+5 \mathrm{t} / \mathrm{ha}$ spent mushroom substrate producing taller plants than other treatments might be attributed to the complementary effect of the manure on each other as both combinations had a conducive soil environment that were richer in nutrient supply for plant uptake. Blay et al. (2001) also noted increased plant height of shallot when organic manure was applied to the soil to supply plant nutrients.

Plot treated with NPK fertilizer gave shorter plants probably because of leaching effects caused by high rainfall in the experimental site, which resulted to the low nutrient status of the soil. Suresh et al., (2004) noted that inorganic fertilizer could cause soil acidity which could decrease plant height of crops. In the same vein, Kaura et al. (2005) reported that organic manure was better than inorganic fertilizers in enhancing plant height in crops. The control plot with no manure or fertilizer application had shorter plants probably because of inherent low fertility status of the soil used for the experiment. 
Table 2: Effect of agro organic wastes and NPK fertilizer on plant (cm) of upland rice

\begin{tabular}{|l|l|l|l|l|}
\hline Treatment & 6 WAS & 9 WAS & 12 WAS & 15 WAS \\
\hline 0 (control) & 51.00 & 51.33 & 56.13 & 54.73 \\
\hline $300 \mathrm{~kg} /$ ha NPK (15 -15- 15) Fertilizer & 51.60 & 59.93 & 58.87 & 57.13 \\
\hline 10 t/ha poultry manure (poultry droppings) & 52.67 & 63.33 & 65.73 & 64.73 \\
\hline 10 t/ha spent mushroom substrate & 51.93 & 59.07 & 64.07 & 65.33 \\
\hline 5 t/ha poultry manure + 5 t/ha spent mushroom substrate & 57.20 & 63.60 & 68.45 & 69.33 \\
\hline LSD $(\mathrm{P}=0.05)$ & NS & NS & NS & NS \\
\hline
\end{tabular}

NS $=$ Not significant at $5 \%$ level of probability

\section{Leaf area}

Table 3 shows the effect of agro organic wastes and NPK fertilizer on leaf area of upland rice. There was no significant difference among the treatments on leaf area throughout the sampling time. Although there were no significant differences on leaf area throughout the sampling time, plot treated with $5 \mathrm{t} /$ ha poultry manure +5 t/ha spent mushroom substrate had the highest leaf area while the control plot had the lowest. Plot treated with 5 t/ha poultry manure $+5 \mathrm{t} /$ ha spent mushroom substrate had the highest leaf area probably due to synergistic effects of the mixture. These combinations were able to improve the physiological growth of rice by adding in more micro nutrient elements to the soil and increase the exchangeable bases of soil, thereby enhancing leaf area expansion. This finding is in agreement with that of Dada et al. (2014) who noted that combinations of manure increased leaf area development of upland rice.

Table 3: Effect of agro organic wastes and NPK fertilizer on leaf area $\left(\mathrm{cm}^{2}\right)$ of upland rice

\begin{tabular}{|l|l|l|l|l|}
\hline Treatment & 6 WAS & 9 WAS & 12 WAS & $15 W A S$ \\
\hline 0 control) & 33.73 & 34.77 & 44.40 & 49.99 \\
\hline $300 \mathrm{~kg} /$ ha NPK $(15-15-15)$ Fertilizer & 31.03 & 40.36 & 45.03 & 50.00 \\
\hline 10 t/ha poultry manure & 41.85 & 42.28 & 47.78 & 59.81 \\
\hline 10 t/ha spent mushroom substrate & 41.15 & 41.87 & 47.35 & 58.50 \\
\hline 5 t/ha poultry manure +5 t/ha spent mushroom substrate & 44.76 & 45.15 & 51.97 & 59.53 \\
\hline LSD $(\mathrm{P}=0.05)$ & NS & NS & NS & NS \\
\hline
\end{tabular}

NS $=$ Not significant at $5 \%$ level of probability

\section{Yield and yield components}

\section{Number of tillers}

The most fundamental component of yield in rice is the number of tillers. As the number of tillers increases, the more the expectations of rice yield. The effect of agro organic wastes and NPK fertilizer on the number of tillers is presented Table 4. There was no significant difference on the average number of tillers among the treatments throughout the sampling time. Although there were no significant differences on number of tillers throughout the sampling time, plot treated with 5 t/ha poultry manure +5 t/ha spent mushroom substrate had the highest number of tillers while the control plot had the lowest. This could be attributable to synergistic effects of the mixture since both mixtures were able to enhance quicker decomposition and release of nutrients owing to their low $\mathrm{C} / \mathrm{N}$ ratio. It can also be attributable to more accessibility of nitrogen, which performed an important function during cell division and better soil environment. Dada et al. (2014) noted that integration of manure increased more tillers formation in rice production.

Table 4: Effect of agro organic wastes and NPK fertilizer on number of tillers of rice

\begin{tabular}{|l|l|l|l|l|}
\hline Treatment & 6 WAS & 9 WAS & 12 WAS & 15 WAS \\
\hline 0 (control) & 4.13 & 8.17 & 9.07 & 10.13 \\
\hline $300 \mathrm{~kg} /$ ha NPK (15-15- 15) Fertilizer & 4.47 & 9.80 & 9.20 & 11.67 \\
\hline 10 t/ha poultry manure & 5.33 & 9.53 & 10.93 & 12.27 \\
\hline 10 t/ha spent mushroom substrate & 4.60 & 8.87 & 9.26 & 11.00 \\
\hline $5 \mathrm{t} /$ ha poultry manure $+5 \mathrm{t} /$ ha spent mushroom substrate & 6.53 & 10.67 & 11.07 & 12.80 \\
\hline LSD $(\mathrm{P}=0.05)$ & $\mathrm{NS}$ & $\mathrm{NS}$ & $\mathrm{NS}$ & $\mathrm{NS}$ \\
\hline
\end{tabular}

NS = Not significant at $5 \%$ level of probability. 
Fresh weight of tillers, dry weight of tillers, dry weight of panicle, 1000 dry weight of grains and grain yield

Table 5 shows the effect of the agro organic wastes and NPK fertilizer on yield and yield components of Upland Rice. There was no significant difference on the yield and yield components among the treatments. The non-significant differences among the treatments on yield and yield components might be attributable to the quality of the agro waste manure used for the experiment which appeared to be low in nitrogen probably due to volatilization during the period of processing at the dump site. Although there were no significant differences on yield and yield components among the treatment, $5 \mathrm{t} / \mathrm{ha}$ poultry manure $+5 \mathrm{t} / \mathrm{ha}$ spent mushroom substrate seemed to produce higher fresh weight of tillers, dry weight of tillers, dry weight of panicle, 1000 dry weight of grains and grain yield followed by poultry manure, spent mushroom NPK and control. The mixture of spent mushroom substrate and poultry manure had the higher yield and yield components probably due to synergic and complementary effect of both manure. The integrated manure provided both micro and macronutrients for effective utilization for better yield and yield components.
Poku et al. (2014) noted that yield and yield components increase in carrot (Daucus carota L.) with organic manure combination. In the same vein, Okonkwo et al. (2012) noted that organic manure is a vital agronomic practice essential for providing plants with nutritional requirements in enhancing yield without any harmful effect to the environment.

Plot treated with poultry manure also had a higher yield and yield when compared to the spent mushroom substrate probably because it was richer in nutrient and had lower $\mathrm{C} / \mathrm{N}$ ratio which quickens its decomposition and release of nutrients for plant uptake. Umanah et al. (2009) reported that poultry manure increased the yield and yield components of rice. Increase in yield and yield component by poultry manure application in other crops such as: pineapple, maize, sorghum had been reported by several authors (Amujoyegbe et al., 2007; Agbede et al., 2008; Orluchukwu and Adedokun, 2014). Notwithstanding of the quality of the agro wastes manure used for the study, their yield ranged from 2.29 to $2.65 \mathrm{t} / \mathrm{ha}$ which is within the potential yield of 2.0-4.0 t/ha (Anon, 2019). The average yield obtained in plots without either of the manure application fell within the range of 1.0 to $1.7 \mathrm{t} / \mathrm{ha}$ which is obtained by peasant farmers in Nigeria (Anon, 2019).

Table 5: Effect of agro wastes manure and NPK on fresh weight of tillers, dry weight of tillers, dry weight of panicle, 1000 dry weights of grains and grain yield of rice

\begin{tabular}{|l|l|l|l|l|l|}
\hline Treatment & $\begin{array}{l}\text { FWOT } \\
(\mathrm{Kg} / \mathrm{ha})\end{array}$ & $\begin{array}{l}\text { DWOT } \\
(\mathrm{Kg} / \mathrm{ha})\end{array}$ & $\begin{array}{l}\text { DWOP } \\
(\mathrm{g} / \mathrm{plant})\end{array}$ & $\begin{array}{l}1000 \\
\mathrm{DWOG} \\
(\mathrm{g})\end{array}$ & $\begin{array}{l}\text { Grain } \\
\text { yield } \\
(\mathrm{t} / \mathrm{ha})\end{array}$ \\
\hline 0 (control) & 1.90 & 0.80 & 26.88 & 26.52 & 1.63 \\
\hline $300 \mathrm{~kg} / \mathrm{ha}$ NPK (15-15- 15) Fertilizer & 2.26 & 0.82 & 29.56 & 26.75 & 2.13 \\
\hline $10 \mathrm{t} /$ ha poultry manure & 2.66 & 1.05 & 30.34 & 29.28 & 2.46 \\
\hline $10 \mathrm{t} /$ ha spent mushroom substrate & 2.34 & 1.04 & 32.96 & 30.09 & 2.29 \\
\hline $\begin{array}{l}5 \text { t/ha poultry manure+ 5 t/ha spent mushroom } \\
\text { substrate }\end{array}$ & 3.00 & 1.42 & 40.58 & 35.32 & 2.65 \\
\hline LSD (P=0.05) & NS & NS & NS & NS & NS \\
\hline
\end{tabular}

FWOT $=$ Fresh weight of tillers, DWOT $=$ Dry weight of tillers, DWOP $=$ Dry weight of panicle, DWOG $=$ Dry Weight of grains, NS = Not significant at $5 \%$ level of probability

\section{CONCLUSION}

This study demonstrated the application of agro wastes manures against NPK fertilizer in upland rice cultivation. Though the agro waste materials and NPK fertilizer had similar growth attributes (plant height and leaf area), yield and yield (number of tillers, fresh weight of tillers, dry weight of tillers, weight of panicle, grains, weight of panicle and 1000 dry weight of grains and grain yield) but the growth, yield and yield components tended to be higher in combination of poultry manure and spent mushroom substrate. Therefore, combination of poultry manure and spent mushroom substrate is recommendable to farmers since they complement each other and served as a better alternative to NPK 15: 15 : 15 fertilizer, which is scarce and expensive.

\section{REFERENCES}

Agbede TM, Ojeniyi SO and Adeyemo AJ (2008). Effect of poultry manure on soil physical and chemical properties, growth and grain yield of sorghum in southwest Nigeria. Am. Eurasian J. Sustain Agr. 2(1):72-77.

Akamigbo F.O.R and Asadu C L A (1983). The accuracy of field textures in a humid tropical environment. Soil Surv and Land Eval.4 (3):63-70. 
Akpokodje G, Lanco F, and Erentein O. (2001). The Nigerian Rice economy in a competitive World: Constraints, opportunities and strategic choices. Nigeria's Rice Economy: State of the Art. WARDA,Bouake, Cote d Ivoire. November, 2001, 738.

Amujoyegbe BA,. Opabode JT and Olayinka A (2007). Effect of organic and inorganic fertilizer on yield and chlorophyll content of maize (Zea mays L) and Sorghum (Sorghum bicolour LMoench). Afr. J. Biotechnol 6 (16):1869-1873

Anon (2017). Rice Cultivation In Nigeria With The Main Producing States. Assessed 6 February 2019. Available: https://www.finelib.com/about/nigeriacash-crops/rice-cultivation-in-nigeria.../145

Blay ET, Danquah EY, Ofosu-Anim J and Ntumy JK (2001). Effect of poultry manure and/or inorganic fertilizer on the yield of shallot (Allium cepa var aggregatum) . Adv. Hortic. Sci. 16 (1): 7-12

Brady NC and Weil RR (2008). The Nature and Properties of Soils 14th ed. Prentice-Hall Inc. New Jersey, USA, 978.

Bremner JM (1996). Nitrogen-total. In Sparks DL et al (ed.) Methods of soil analysis. Part 3. SSSA Book Ser. 5. SSSA, Madison, WI, 1085 - 1122.

Busari MA, Salako FK and Adetunji MT (2008). Soil chemical properties and maize yield after application of organic and inorganic amendments to an acidic soil in south western Nigeria. Spanish J. Agr Res. 6:691-699.

Dada OA, Togun AO, Adediran JA and Nwilene FE (2014) Growth, Nutrient Uptake Efficiency and Yield of Upland Rice as Influenced by Two Compost Types in Tropical Rainforest-Derived Savannah Transition Zone. Agric Sci. 5: 383-393.

Fakayode S B (2009). Technical efficiency and factor productivity in upland and lowland rice production systems in Kwara State, Nigeria. PhD Dissertation of University of llorin, Nigeria.

Gil MV, Carballo MT and Calvo LF (2008). Fertilization of maize with compost from cattle manure supplemented with additional mineral nutrients. Waste Manag. 28:1432-1440.

Ibedu MA, Unambra RPA and Udealor A (1988). Soil management strategies in relation to farming system development in Southwestern Agricultural zone of Nigeria. Paper presented at the National Farming System Research Workshop, Jos, Plateau State, Nigeria.

Idiong IC (2006). Evaluation of Technical, Allocative and Economic Efficiencies in Rice Production Systems in Cross River State, Nigeria. Unpublished Ph.D Dissertation. Micheal Okpara University of Agriculture, Umudike.

Kaur K, Kapoor KK, Gupta AP (2005). Impact of organic manures with and without mineral fertilizers on soil chemical and biological properties under tropical conditions. J. Plant Nutr. Soil Sci.168:117-122.
Nelson DW and Sommers L E (1982). Total Carbon, Organic Carbon and Organic matter. In page, A. L. et al (eds) methods of soil analysis Part 2. Agron. Monogra - 9. Second edition ASA and SSSA. Madison Wisc. 539-579.

Nwankwo CN and Ehirim CN. (2010). Evaluation of aquifer characteristics and ground water quality using geoelectric method in Choba, Port Harcourt. J. Sch. Res. Library 2: 396-403

Okalebo JR, Gathua KW and Woomer PL (2002). Laboratory methods of soils and plant analysis: A working manual, 2 Ed. Sacred Africa, Nairobi, Kenya, $36-37$

Okonkwo Cl, Onyibe C, Nwite J, Igwe T.S, Njoku, C and Mbah C.N. (2012) Physical Characteristics and Maize Grain Yield in an Ultisol in South Eastern Nigeria Amended with Four Animal Manures. Int. Res. J. of Agric. Sci. and Soil Sci., 2: 77-80.

Olsen S R and Sommers LE (1982). Phosphorus. Page $\mathrm{AL}$, Miller $\mathrm{RH}$, and Keeney DR [eds.] Methods of soil analysis, part 2 - No 9. Am. Soc. Agron. Madison, WI, 403-430.

Orluchukwu J A and Adedokun O M (2014). Comparative effects of poultry manure and spent mushroom substrate on the growth and yield of pineapple (Ananas comosus) in Nigeria. Afri. J.Agr Res. 9(26) : 2041-2044.

Poku PA, Agyarko K, Dapaah HK and Dawuda MM (2014). Influence of Mucuna pruriens Green Manure, NPK and Chicken Manure Amendments on Soil Physico - Chemical Properties and Growth and Yield of Carrot (Daucus carota L.) J. Agric. and Sustain. (1): $26-44$

PricewaterhouseCoopers (PwC) (2018). Boosting rice production through increased mechanization.Assessed6February2019. Available: $\underline{h t t}$ ps://www.pwc.com/ng/en/assets/pdf/rice-productionarticle.pdf

Rapu SC (2016). Evaluating the impact of policies on production efficiency of Nigeria's rice economy. $\mathrm{PhD}$ Dissertation of Walden University, Minneapolis, Minnesota, USA.

Remison SU (2005). Arable and Vegetable Crops of the Tropics. Gift print associate, Benin City, 39.

Remison SU and Lucas EO (1982). Effects of planting density on leaf area and productivity of two maize cultivars in Nigeria. Exp. Agr. 18:93-100.

SAS (2003). Statistical analytical system for linear models: A guide to the ANOVA and GLM procedures SAS Inst. Cary, N.C.

Sheldrick B and Hand Wang C, (1993). Particle-size distribution. In: Carter, MR (Ed.), Soil Sampling and Methods of Analysis. Canadian Society of Soil Science, Lewis Publishers, Ann Arbor MI, 499-511

Singh BN, Fagade S, Ukwungwu MN, Williams C, Jagtap SS, Oladimeji O, Efisue OA, and Okhichievbie O (1997). Rice Growing Environments and Biophysical Constraints in Different Agro ecological Zones of Nigeria. Meteorological J. 21: 34- 44 
Suresh DS, Goyal KK, Mundra M (2004). Microbial biomass carbon and microbial activities of soils receiving chemical fertilizers and organic amendments. Arch. Agron. Soil Sci50: 641-647.
Umanah EE, Ekpe EO, Ndon BA, Etim ME and Agbogu MS (2003). Effects of poultry manure on growth characteristics, yield and yield components of upland rice in South Eastern Nigeria. J. Sustainable Agric and the Environment 5(1): 105-110.

\footnotetext{
Cite this Article: Orluchukwu, J.A.; Emem, Alban; Omovbude, S. (2019). Effect of Agro- organic wastes and NPK Fertilizer on Upland Rice Performance in Port Harcourt, Rivers State, Nigeria. Greener Journal of Agricultural Sciences 9(1): 102-109, http://doi.org/10.15580/GJAS.2019.1.030919045.
} 